\title{
Linguistic Variation and Change in Nawfija Speech Community
}

\author{
Nwagalaku Chineze \\ Department of Linguistics, Igbo and Other Nigerian Languages, University of Nigeria, Nsukka, Nigeria \\ Obiora Harriet Chinyere \\ Department of Linguistics, Igbo and Other Nigerian Languages, University of Nigeria, Nsukka, Nigeria \\ Christopher Chinedu Nwike ${ }^{1}$ \\ Department of Linguistics, Igbo and Other Nigerian Languages, University of Nigeria, Nsukka, Nigeria
}

\begin{abstract}
The focus of this study is on linguistic change and variation in the Nawfija speech community. It distinguished dialect from other similar words and contrasted the traditional Igbo dialect with the Nawfija dialect of the Igbo language on an equal footing. The types of dialectal variations found in the Igbo Nawfija dialect were investigated in this study, as well as the question of dialect supremacy. For the creation of standard Igbo, some suggestions have been made.
\end{abstract}

Index Terms - language, linguistic variation, standard variety of Igbo and Nawfija variety of Igbo language

\section{INTRODUCTION}

The empirical study of language is referred to as linguistics. In other words, it is concerned with the systematic study of languages, as languages vary in terms of their origins, varieties, and status. From this vantage point, it's easy to see how language is constantly changing. Language dynamism refers to both language transition and language loss, not just variation that leads to dialect. According to (http://en.citizendium.org/wiki/linguisticvariation), linguistic variation is the degree of discrepancies between various languages around the world, and this field of study can be considered a branch of linguistics research. The linguistic difference between speakers of a language is what one might claim occurs mainly in pronunciation/accent in relation to the study of language and culture. It can also be related to word/lexicon selection and, ultimately, a preference for a certain grammatical pattern.

The Concept of Speech Community

Speech is a key discourse of sociolinguistic phenomena. A speech culture, according to Olaoye (2007), is a group of people who share the same values, norms, attitudes, and other aspects of language use and structure. They both have similar perspectives on speech laws and perception. Speech is a major sociolinguistic discourse. Olaoye (2007) defines a speech culture as a community of people who have similar beliefs, norms, attitudes, and other aspects of language use and structure. They have a common outlook on speech laws and interpretation. Given the foregoing context, the focus of this research is on linguistic variation and shift in the Nawfija speech culture, which can be viewed as a dialect variation of the Igbo language. The Nawfija dialect, a variant of the Igbo language, is the subject of this research. Nawfija is a town in Anambra State's Orumba South Local Government Area. The aim of this study is to achieve the following objectives.

1. Identification of the linguistic variations in the Nawfija speech community

2. To show that this variation is not substandard Igbo Language but rather a variant of Igbo Language due to regional factors.

3. To identify and analyze the types of variation in Nawfija dialect of Igbo Language.

The scope of this study is as follows:

1. Comparison of Nawfija dialect and the Standard Igbo

2. The differences in meaning in these two dialects of Igbo Language

3. The different types of dialect variation

The significance of this study shall be of much relevance in the following ways:

1. Serve as enlightenment not only to the native speakers of Nawfija dialect but also to the users of Igbo Language in general.

2. It will serve as a reference material to other researchers in related fields

3. It will also bring to light features that are peculiar to the dialect which may contribute to the development of Igbo language and perhaps to general linguistics theory.

\footnotetext{
${ }^{1}$ Corresponding email: nwikechristopher1@gmail.com
} 
The data for this research work was gathered through an oral interview and informal conversation. Information on the town's history was gathered using these methods, and some differences in the narration of words in the Nawfija dialect were noticed. A hundred-word compilation was also used to see whether there were any differences in the names of these words in the Nawfija dialect.

\section{DEFINITION OF SOME IMPORTANT TERMS AND TERMINOLOGIES}

\section{A. Language}

Human language is a means of human communication that allows people to share their opinions, emotions, and ideas. Language is a means of communication used by humans that includes speech and writing, according to Anagbogu, Eme, and Mbah (2001). They went on to say that language is a type of communication in which people use writing systems, signs, or symbols to communicate their thoughts, feelings, emotions, and desires.

\section{B. Dialect}

Dialect refers to a group of people's unique way of speaking a language that differs from the standard. The literal sense of the word "dialect" and its linguistic meaning, according to Akmajian, Demers, and Harnish (2004), are in stark contrast. According to him, a dialect is a substandard use of a language, or, in other words, an incomplete, corrupt, or pure form of a standard language. It refers to a distinct type of a language in linguistics and does not carry any such judgment.

\section{Variation}

Variation is a change especially in the amount or level of something. It can also be said to be a thing that is different from other things in the same group. So, variation in dialects can be said to be different in the dialects of the same language.

\section{Idiolect}

An idiolect is the variety of language that is spoken by each individual speaker of a language. Idiolect means the form of a language spoken by a single individual. Synonymously, it can be said that the way there is ones form of language use in a particular language, so there is with language variation as it involves levels of possible divergences, shifts or differences between how words are used by a particular set group in a speech community. From the foregoing, it can be said that there cannot be two same speaker of a particular language who speaks alike. This is to say that in a speech community, individuals speak or use language in their different ways, still, they communicate and pass across information from one person to another with meaning loses. Dialects themselves are collections of idiolects and thus so are languages.

\section{EMPIRICAL FRAMEWORK AND OVER VIEW}

The study of linguistics variation is always evident in language study because, variance in there is human the human languages sin an individual may decide to use a language in his or her own way in different instances and occasions while another individual from same speech community will still express that same message in another way. On the part of the language use of different speakers in a particular speech community according to (http://en.wikipedia.org/wiki/variation_linguistic), it can be said that the act of the language use is systemic in nature, in terms of one's pattern of pronunciations; word formation/morphology, grammar and word choices depending on the possible non-linguistic factors. However, these factors maybe as a result of the speaker's intension or purpose in which he or she is communicating. It can also be as a result of the relationship that exist between the speaker and hearer, as well as the possible structure of the population that the speaker have and finally, the production circumstances at the point the speaking is using utterances. Based on the foregoing, all these discussed factors are in turn, raise the consciousness of scholars in area of language study on the relationship and effect of language and the society, thus given rise to sociolinguistics.

In consonance with the above information, it can be said that dialect is a form of language variance that occurs in grammar and vocabulary. It can also involve variation in sound pattern. An instance a situation by which one says 'coming', and one ended up say I am coming ( $\left.\left.\mathrm{k}^{\wedge} \mathrm{mi}\right]\right)$, and another says 'I am coming ( $\mathrm{k}$ mi]), one can actually understand that the difference lies on the accent. Another instance can be in a case of father (fæder) and father (fahada). In other words, when one says 'I got to go and another says that I gat to go', it can be said that it I a change that occurred due to the presence of dialect reflection of the language. In Igbo language, an instance can be drawn, where one says 'Ihe nke a Obụ osikapa, and another says, ife nke a, Owụ osikapa (is this thing rice?), it can be discovered that it is the dialectal influence that manipulates the statement where the former is in standard Igbo while the later is in the dialect of Igbo language.

\section{A. Dialect Variation}


Yule (2004) defines dialectal variation as differences in dialects of a language in pronunciation, vocabulary and a different grammatical form. In line with the foregoing, Akmajian et al (2004) came up with some dialectal examples in both the American and British English. According to Akmajian et al (2004), they are:

$\begin{array}{ll}\text { British (Terms/phrases) } & \text { American (Terms/phr } \\ \text { Car park } & \text { Parking lot } \\ \text { Coach } & \text { bus } \\ \text { Garage } & \text { service station } \\ \text { Lay by } & \text { rest area } \\ \text { Lift } & \text { elevator } \\ \text { Lorry } & \text { truck } \\ \text { Petrol } & \text { gasoline } \\ \text { Undergraduate (or tube) } & \text { subway } \\ \text { Call box } & \text { telephone booth } \\ \text { Telephonist } & \text { switch board operator } \\ \text { Gin and French } & \text { dry martini } \\ \text { Minerals } & \text { soft drinks }\end{array}$

According to Nwoga (1975), because there is no central place for a town to meet for their various interests, it then makes them lack communication with one another. This is to say that s community is therefore isolated from the others in a town for meetings of various kinds, because there is no rallying point. When this happens each community holds its meeting separately. This encourages dialect variation. Variations therefore occur in both vowels, consonants and in many cases in actual word use. As they keep meeting individually, it is only natural that new sounds will be introduced within the community bringing out variations. In his words he said that "Dialect variations are mainly pronunciation". That means that most variations in dialect are mainly because of the way they are pronounced and a slight different in their spellings. Essien (1990) is of the view that dialect variation results from the complete diffusion of linguistic changes. Each point of difference stems ultimately from the failure of innovation to be adopted by all speakers of the language when two or more languages become sufficiently divergent, they are said to be genetically related language". Human dialect is derived from classes and is dependent on a number of factors, the most important of which seem to be social status, faith, and ethnicity," writes Wardhaugh (1993).

The discovery that variance is far from being a "defect" in language simply shows its true existence as a result of the preceding. Human language is a rule-governed structure that allows for a great deal of versatility and innovation. There is no evidence that 'non standard' dialects are less effective as a means of communication than the so-called standard language. To put it another way, linguistic diversity does not imply linguistic inferiority. Instead, the issue is the language community's attitude toward speakers of these dialects. Differentiation within a language would ultimately lead to the formation of different languages due to the force of variation and shift in a language.

\section{Kinds of Dialectal Variation}

On aspects of language variations, focus is on grammar and society. This simply means that identifying a dialect necessitates knowledge of the dialect's phonetics, phonology, morphology, syntax, and semantics, as well as knowledge of who speaks it.

\section{Phonetic Variation}

A phonetic variation is described as a change in pronunciation that does not affect the phonemic level of the grammar, according to the book Language Files. There are two examples given. The following is an example of New York alveolar consonants. The alveolar consonants in some New York City dialects are routinely developed with contact between the tongue tip and the upper teeth (i.e. they are dento-alveolar), while the alveolar consonants in so-called regular dialects are not dental. The (t) in the word "two" in New York English (NYE) is formed by making contact between the tongue tip and the teeth. This is not the case in so-called Standard English. Dentals are not always recognized as alveolar consonants. Since there is no distinction between New York English and Standard English at the phonemic stage, this is a phonetic variation. Both have the same phonemics for alveolar consonants. Thus, between the two dialects, the position of articulation of (t) differs slightly. Standard English speakers only produce alveolar consonants with contact between the tongue tip and upper front teeth on rare occasions, such as in words like (tenth). In fact, the distinction is found at the allophone level rather than at the phoneme level.

\section{Phonological Variation}

Variation in pronunciation can be found at the phoneme level or at the level of phonotactic restrictions on syllable form, for example. The sequences $\mathrm{Cr}$ and $\mathrm{Cl}$ (c stands for consonant) are forbidden in unstressed syllables in some African American English (AAE) or dialects. As a result, "professor" is "professor." This is a case of phonological variation since the word professor has a /r/ as the second phoneme in standard American English (SAE), but in AAE, /r/ is simply not permitted to appear in this position. Since we can distinguish a specific difference in phonotactics between $\mathrm{AAE}$ and $\mathrm{SAE}$, this is a case of phonological variation.

$\mathrm{Cl}$ and $\mathrm{Cr}$ clusters are not permitted in AAE, but they are permitted in SAE. This simply means that the phonological rules of the two dialects vary significantly; specifically the inventory of possible forms varies from one to the other.

\section{Morphology Variation}


According to 'language archives,' examples of morphological variation can be found in the speech of Northern England and Southern Wales, where the/-s/suffix is used as a general present tense maker. In many other English dialects, /-s/ is only used to form the present tense in third person singular forms.

\section{Example:}

1. I likes him

2. We walks all the time

Another example comes from Appalachian English, which has a variety of non-standard past tense forms, such as 'Et' for "ate" and "her" for "heated."

\section{Syntactic Variation}

Syntactic variation, as the name implies, refers to variations in syntactic structure between dialects. The word "gone" is often used as an auxiliary in many southern dialects, as in "she done already told you" or "I done finished a while ego." This is also not the case in SAE. The use of the double modal 'I may be able to do it'. Another example is the use of so-called double negatives, such as in the phrase "I didn't see anyone.

\section{Semantic Variation}

When we speak about semantic variation, we also talk about how different dialects have different meanings for the same words, or how different words are used for the same thing in different dialects. This is more precisely known as the analysis of lexical semantic variation. That's a fancy way of saying that we're looking at word sense variation. The compound word "knocked up" is an example of a single word with several meanings. It means 'to rouse from sleep' in England and 'to make pregnant' in the United States. What one takes to the store is an example of various terms being used for the same thing. In some dialects, it is referred to as a bag, while in others, it is referred to as a sack.

\section{B. Dialects and the Interplay of Regional and Social Factors}

A New York City / / Regional variation is only one of several forms of linguistic variation that can exist between speakers of the same language. (See http://grammar.about.com/od/il/g/linguisticvariationterm.htm for more information.). As previously mentioned, the regional dialect is a classic example of a dialect, with the idea that speakers of the dialect form a cohesive speech group that lives in relative isolation from speakers outside the community. Such geographical isolation is becoming increasingly uncommon, and the population of the United States as a whole is so geographically and socially mobile that speaking of regional dialects in any pure sense is becoming increasingly difficult. A particular linguistic feature of a regional dialect can be influenced by social factors, particularly in large urban areas. The pronunciation of / / in New York city speech is a fascinating example of the influence of "social status" on a regional dialect. The so-called r-less dialect of New York City is so well-known that it is often mocked, particularly by New Yorkers who speak it themselves. It is a common misconception that speakers of the dialect lack / / in words like car, card, four, fourth, and so on, but this is not the case, as revealed by an intriguing study by sociolinguist Willian Labov (1972). Labov's theory was that the pronunciation of / / in New York City varies depending on one's social class. Finally, he observed a change between casual and emphatic pronunciation, but it is minor, and the distinction between causal and cautious language styles is important in syntactic variation as well.

\section{Mutual Intelligibility}

Knowing that idiolectal and dialectal variation exist, how do we know if two language varieties or two dialects are dialects of different language altogether? Akamajian et al (2004) answers this question based on the notion of mutual intelligibility. Even if native speakers of a language, such as English, use the language differently, their languages are similar enough in pronunciation, vocabulary, and grammar to enable mutual understanding. A New Yorker, a Texan, and a Californian may notice variations in each other's languages, but they can understand and recognize each other as speaking the same language (despite all the jokes to the contrary). As a result, speaking the "same language" does not require two speakers to speak identical languages, but rather languages that are very similar. It's worth noting instances of one-way intelligibility between speakers of distinct but traditionally related languages. Even if one group of speakers understands another, they cannot be assumed to speak the same language unless the second group understands the first; hence, reciprocal intelligibility is critical in determining if two languages are the "same."In fact, language variation is so widespread that each language is essentially a continuum of languages that varies from speaker to speaker and from group to group, with no clear distinction between them

\section{WORD/DATA PRESENTATION}

In this section we make a presentation of the 100 word list collected during the field work. This list will form the data used for analysis. 
TABLE ONE

\begin{tabular}{|c|c|c|c|c|c|}
\hline $\mathbf{S} / \mathbf{N}$ & English Language & $\begin{array}{l}\text { Standard Igbo } \\
\text { Language }\end{array}$ & Phonetic Transcription & Nwafija Dialect & Phoectic Transcription \\
\hline 1. & No & Ḿbò & $/ \mathrm{mb} \grave{\alpha} /$ & Èè,èélè & éè/,/èélè/ \\
\hline 2. & Night & Abòli & /àbò̀lì/ & ányàsừ & /ánàsv̀/ \\
\hline 3. & Leg & Úkwú & /úkwú/ & ókpà & /Jkpà/ \\
\hline 4. & What & Gìnī & /gìnī/ & òóǹnū & /ợ̂́nū/ \\
\hline 5. & One & Ótù & /ótù/ & Ḿvú/ǹnà $\bar{\alpha}$ & /mvv̛́ńnà $/$ \\
\hline 6. & Cloth & Akwà & lákwà/ & àkwá & /àkwà/ \\
\hline 7. & Come & Bìá & /bìá/ & bìá & /Bìá/ \\
\hline 8. & Now & Ù'gbứà & /ùgbúà/ & ùdùú & /òdóń/ \\
\hline 9. & Thank you & Dàálù & /dáàlò/ & ìmégwó & /Imegwō/ \\
\hline 10. & Cup & İkó & fikó/ & ìkó & /ikó/ \\
\hline 11. & Water & Mmiri & $/ \mathrm{m} \mathrm{m} \overline{\mathrm{I}} \mathrm{r} \overline{\mathrm{I}} / \mathrm{s}$ & Mmìrí & /mmírì/ \\
\hline 12. & Key & Nwá igódó & /Dwá igódó/ & òtúgwó & /Jtúgwכ/ \\
\hline 13. & Door & úzò & /ózo/ & úzò & /óza/ \\
\hline 14. & Hair & Nùù & /nùù/ & nùù & /Dùù// \\
\hline 15. & Wrapper & Úkwùákwá & /úkwùákwá/ & ògòdò & /Jgadכ/ \\
\hline 16. & Plate & Eféré & /éfélé/ & éfélé & /Éféré/ \\
\hline 17. & Bye bye & Nàá gbáóó & /nàá gbóó/ & Nàá gbóó & /nàà gbóó/ \\
\hline 18. & Head tie & İchàfù & /11tàfú/ & ìchàfù & líţâfù/ \\
\hline 19. & Garden egg & Anàrà & /À̀yàà/ & Anàrá & /Ánàrà/ \\
\hline 20. & Stone & òkwútē & /òkwútē/ & mkpúmé & /mkpúmé/ \\
\hline 21. & Box & İgbé & /İgbé/ & ákpàtì & /Ákpàti// \\
\hline 22. & Matches & Mkpá okū & /mkpáokú/ & Mkpá okū & /mkpá כkv́/ \\
\hline 23. & Mirro & Ènyò & /ènò/ & ènyò & /ènò/ \\
\hline 24. & Surrounding & Mbárá & /márá/ & mbárá & /márá/ \\
\hline 25. & Malice & Ėsèmókwú & /èsèmókwú/ & èsèmókwú & /Ėsèmókwú/ \\
\hline 26. & Now & Ứgbúà & /úgbà/ & ừdún & /v̀dóń/ \\
\hline 27. & Here & Ėbéà & /ébéà/ & kàn & /káń/ \\
\hline 28. & Welcome & Nnóò & /দ́nวכ/ & ndèèwó & /Jjdéèwó/ \\
\hline 29. & Old person & òkènyè & /ókènè/ & ókènyè & /ókènè/ \\
\hline 30. & Plantain & Ờgèdè & /ògèdè/ & ừnèákánkútà & /ừnèákájkv̀tā/ \\
\hline 31. & Bitter kola & Akínū & /ákíínū/ & ừgórò & /ừgórò/ \\
\hline 32. & Comb & Mbó & $/ \mathrm{mbo} /$ & mvó & $/ \mathrm{mgv} /$ \\
\hline 33. & Bottle & Kátámá & /kátámá/ & ŕóm & /ứróm/ \\
\hline 34. & Bed & Àkwà & làkwà/ & àkwà & /Àkwà/ \\
\hline 35. & Tree & Ósísí & /ósísí/ & óshíshí & 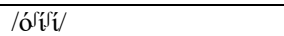 \\
\hline 36. & Spoon & Ngàzì & /naàz'/ & nkóbò ngàdzì & /ṇkobo ǹggàzì/ \\
\hline 37. & Hand fan & Akừpè & /àkừpè/ & àkừpè & /àkừpè/ \\
\hline 38. & Toe & Mkpísí úkwū & /"mkpísí ứkwū/ & ḿpuứrứ ứkwū & $/{ }^{\mathrm{m}} \mathrm{k}$ kứrứ ứkwū/ \\
\hline 39. & Friend & Ënyì & /ènì/ & ényì & lénì/ \\
\hline 40. & Old & Óchié & /ótfiél & ńkā & /ńkāal \\
\hline 41. & Shoe & Ákpúkpú úkwú & /ákpúkpú v́kwō/ & ákpúkpú úkwū & /ákpúkpú v́kwv̄/ \\
\hline 42. & Outside & Ėzí & lèzíl & èzí /író & /Èzí/író/ \\
\hline 43. & Village square & Ámá & lámál & Ámá & /Ámá/ \\
\hline 44. & Ring & Ólà ákā & /Jlàákā/ & Ólàákā & /Jlàákā/ \\
\hline 45. & Mother & Ńné & /íné/ & Ńné & /innnél \\
\hline 46. & Father & Ńnà & /ńnà/ & Ńnà & /ńnà/ \\
\hline 47. & Rope & Ùंdò & /v̀do/ & ùdò/érírí & /v̀do/érírí/ \\
\hline 48. & That place & Ébé àhù & /ébé àhù/ & íbé àhù & /íbé àhò/ \\
\hline 49. & That time & Ógè áhù & /ógé áhò/ & ḿgbè áhù & /mgbe áhù/ \\
\hline 50. & Small & Óbérē & /óbérē/ & Óbérē & /Óbérē/ \\
\hline 51. & Fence & Ògìgè & /ògìgè/ & Ògìgè & /Ögìgè/ \\
\hline 52. & Lie & Àsí & /àsí/ & à)í & /à)îl/ \\
\hline 53. & Farm & Úgbō & /úgbō/ & Úbì & /Ứbì/ \\
\hline 54. & Thread & Érírí & /érírí/ & Érírí & /éríríl \\
\hline 55. & Knife & Ḿmà & /mmà/ & ḿmà & /mmà/ \\
\hline 56. & Back & Àzú & /àzú/ & Àzú & /Àzú/ \\
\hline 57. & Again & Òzó & /ozs/ & Òdó & /odo/ \\
\hline 58. & Swallow & Òlúló & /òlúló/ & Òlúló & /Òlúló/ \\
\hline 59. & Carry it & Bùrú yā & /búrù jā// & vúrù yā & /Vúrù jā/ \\
\hline 60. & Head & Ílsí & /síí/ & Í́shí & lífhí/ \\
\hline 61. & Bee & Anū & /ánó/ & Ánú & /Áńú/ \\
\hline 62. & Nail & Ǹtú & /ìtú/ & ǹ̀tú & /ìtúl/ \\
\hline 63. & Day & Úbòchì & /óbotyi// & úbòchì & /v́otil/ \\
\hline 64. & Show & Gòsí & /gòsí/ & Gòshí & /gò)íl/ \\
\hline 65. & Sickness & 'Orì̀ & /orìà/ & Órìà & /orià/ \\
\hline 66. & Load & Íbú & /Í́bú/ & 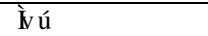 & /Ívú/ \\
\hline 67. & Stealing & Óhī & /óhī/ & Óshī & /ófî̀ \\
\hline 68. & Read & Gùó & /gús/ & Gùó & /gúo/ \\
\hline 69. & Odour & Ísì & /ísì/ & Íshì & $/|\overline{1}| \mathrm{i} /$ \\
\hline
\end{tabular}




\begin{tabular}{|c|c|c|c|c|c|}
\hline 70. & Stick & Ósísí & /ósísí/ & Óshíshí/ḿkpárá & 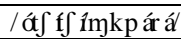 \\
\hline 71. & Leadership & Óchíchí & /otgitfíc/ & óchíchí/òdúdú & /otfítyí/òdúdú/ \\
\hline 72. & Laugh & Óchì & /otgíl & Óchì & $\log \mathrm{y} /$ \\
\hline 73. & Get out & Pùó & /pús/ & Fùó & /fús/ \\
\hline 74. & Hand & Áká & láká/ & Áká & /Ákál \\
\hline 75. & High & Élù & /èlù/ & Èlù & /Èl/ \\
\hline 76. & Greeting & Èkélé & /èkélé/ & Èkéné & /Èkéné/ \\
\hline 77. & Cook & sìé & /sìé/ & Shìé & /Jié/ \\
\hline 78. & Sit down & Nòdí ànì & /nodÍlànÍ/ & nòró ànà & /norəànà/ \\
\hline 79. & There & Ébé àhù & /ébé àhó/ & Íbé àhù & /Íbé àhú/ \\
\hline 80. & Said & Sìrì & /sÍrì/ & Shìrì & /J'́ŕĺ/ \\
\hline 81. & Year & Áfò & /áfo/ & Áwhò & /áio/ \\
\hline 82. & Tall & Ógólógó & /ógólógó/ & ógólógó & /ógólógó/ \\
\hline 83. & Blood & Óbàrà & /obàrà/ & Òbàrà mméè & /obàrà mméè/ \\
\hline 84. & Market & Áhíá & láhÍá/ & Áhíá & /áhíá/ \\
\hline 85. & Sleep & Úrá & /órá/ & Úrá & /v́rá/ \\
\hline 86. & Madness & Árá & lárá/ & Árá & lárá/ \\
\hline 87. & Drink & Nùó & /ท̀v์s/ & ǹùó & /ๆेv́s/ \\
\hline 88. & Oil & Ḿmánū & /mmánv̄/ & Mánū & /mánv̄/ \\
\hline 89. & Face & Îhú & /îhú/ & İhú & /íhú/ \\
\hline 90. & Yes & Éं̄̄ & /éē/ & Ėéȳ̄ & /èéjī/ \\
\hline 91. & Enter & Bàtá & /bàtá/ & Bàtá & /bàtá/ \\
\hline 92. & Suffering & Áhúhú & /áhúhú/ & áwhúwhú & /ánúró/ \\
\hline 93. & Blindness & Í́sì & /ísì/ & Íshì & $/ \mathrm{i} \int \mathrm{i} /$ \\
\hline 94. & Houses & Úlò & /úlı/ & Úlò & /úlo/ \\
\hline 95. & Two & Àbùó & /ábùo/ & İbùó & /İbùs/ \\
\hline 96. & Name & Áhà & /áhà/ & Áhó & /áho/ \\
\hline 97. & Stomach & Áfó & /áfo/ & Áwhó & /áīo/ \\
\hline 98. & Tongue & Íré & líré/ & Íré & líré/ \\
\hline 99. & Come down & Gbábàtá & /gbábàtá/ & Gbàbátá & /gbábàtá/ \\
\hline 100. & Children & Úmùákā & /ómùákā/ & Úmùázjì & /úmùázì/ \\
\hline
\end{tabular}

\section{A. Data Analysis}

A cursory look at the list shows a number of variations between standard and Nawfija. These variations will constitute the basis of our analysis.

\section{The Variation Observed in Nawfija Dialect of Igbo Language}

2. Lexical Variation

From the above data the researcher observes that there are some lexical variations between the Standard Igbo and the Nawfija dialect. This has to do with the vocabulary of the language. Lexical variation in this context brings to light things that are called by different names in Nawfija dialect other than what they are called in the standard form of Igbo language. This means, things or items that are not called by their standard form names in Nawfija dialect. Below is a tabular representation of some of these instances.

\begin{tabular}{|c|c|c|c|}
\hline $\mathbf{S} / \mathbf{N}$ & English & Standard Igbo & Nwafija dialect \\
\hline 1. & No & Ḿbà & Éè, élè \\
\hline 2. & Night & Ábàlí & ányùù \\
\hline 3. & Leg & Úkwú & Ókpà \\
\hline 4. & What & Gínī & òónnū \\
\hline 5. & One & Ótù & mvú nnàà \\
\hline 6. & Now & Ùgbúà & Ùdùú \\
\hline 7. & Thank you & Dàálù & ímégwó \\
\hline 8. & Key & Nwá igódó & ótúgwó \\
\hline 9. & Stone & Òkwútè & mkpúmè \\
\hline 10. & Here & ébéà & Kán \\
\hline 11. & Box & ìgbé & ákpàtì \\
\hline 12. & Welcome & Nnóò & ndéèwó \\
\hline 13. & Plantain & ògèdè & ùnèákánkútà \\
\hline 14. & Bitter kola & Ákíínū & Ùgórò \\
\hline 15. & Comb & Mbó & Mvó \\
\hline 16. & Bottle & Kátámá & Úróm \\
\hline 17. & Spoon & Ngàzì & nkóbò ngàdzì \\
\hline 18. & Farm & Ùgbō & Úbì \\
\hline 19. & Sit down & Nòdí ànì & nòró ànà \\
\hline 20. & Yes & Éē & Ééȳ̄ \\
\hline 21. & Children & Úmùákā & Úmùázjì \\
\hline
\end{tabular}

These are some of the lexical variation in the Nawfija dialect of Igbo language.

\section{Phonological variation}


This is a form of pronunciation variation that has an impact on the phonemic level of grammar, which includes things like syllable shape. Before we go any further, let's take a look at some of the phonological differences found in this Igbo dialect.

TABLE THREE

\begin{tabular}{|c|l|l|l|}
\hline S/N & English & Standard Igbo & Nwafija dialect \\
\hline 1. & Comb & Mbó & Mvó \\
\hline 2. & Tree & Ósí & Òshíshí \\
\hline 3. & That place & Ébé àhù & íbé àhù \\
\hline 4. & That time & Ògè áhù & mobè àhù \\
\hline 5. & Lie & Àsí & Àshí \\
\hline 6. & Again & Òzó & Òdó \\
\hline 7. & Carry it & Bùrú yā & vùrú yē \\
\hline 8. & Head & ís̀̀ & Íshì \\
\hline 9. & Show & Gòsí & Gòshí \\
\hline 10. & Load & Ībú & Ívú \\
\hline 11. & Stealing & Òrī & Óshī \\
\hline 12. & Odour & ís̀̀ & Íshì \\
\hline 13. & Get out & Pùó & Fùó \\
\hline 14. & Greeting & Ékélè & Ékénè \\
\hline 15. & Cook & Síé & Shìé \\
\hline 16. & There & Ébé àhù & íbé àhú \\
\hline 17. & Said & Sì̀̀ & Shìrì \\
\hline 18. & Year & Àfò & Áwhò \\
\hline 19. & Two & Àbúó & Ìbùó \\
\hline 20. & Stomach & Àfó & Áwhó \\
\hline 21. & Suffering & Àhúhú & Áwhúwhú \\
\hline
\end{tabular}

In the diagram above, the phonological differences between the Nawfija dialect of Igbo language and the standard form of Igbo language are shown. The sound / $\mathrm{v} /$ is used in most places in the Nawfija dialect where the sound /b/ is used in standard Igbo. This means that the Nawfija dialect uses voiced labio dental fricative / $\mathrm{v} /$ in most instances where regular Igbo uses voiced bilabial plosives $/ \mathrm{b} /$.

TABLE FOUR

\begin{tabular}{|c|l|l|l|}
\hline S/N & English & Standard Igbo & Nwafija dialect \\
\hline 1. & Comb & Mbó & Mvó \\
\hline 2. & Carry it & Bùrú yā & vùrú yē \\
\hline 3. & Load & íbú & Ívú \\
\hline
\end{tabular}

Another instances is the use of the sound / $/$ / which is orthographically written as "Sh" that is palate alveolar fricative in Nawfija dialect as against the sound /s/ which is orthographically written as ' $\mathrm{S}$ ' that is voiceless alveolar fricative which is in use in standard Igbo.

Some examples are below:

\begin{tabular}{|l|l|l|l|}
\hline \multicolumn{2}{|l|}{ TABLE FIVE } & Nwafija dialect \\
\hline S/N & English & Standard Igbo & Óshíshí \\
\hline 1. & Tree & Òsísí & Ashí \\
\hline 2. & Lie & Ásí & Ísí \\
\hline 3. & Head & ísí & Gòshí \\
\hline 4. & Show & Gòsí & Ísì \\
\hline 5. & Odour & İsì & Shìé \\
\hline 6. & Cook & Sìé & Shìrì \\
\hline 7. & Said & Sìrì & \\
\hline
\end{tabular}

Lastly on the dominant phonological variation observed in this dialect is the introduction of a new sound to the sound system of Igbo language. We can observe the use of the sound / $\$$ / voiceless bilabial fricative orthographically written as "wh" which has not been included in the sound system of the standard Igbo and also the sound /3/ voices palate alveolar fricative, orthographically written as "Zj" which has not also been included in the sound system of the standard Igbo. Examples are below:

\begin{tabular}{|c|l|l|l|}
\hline S/N & TABLE SIX & Nwafija dialect \\
\hline 1. & Year & Standard Igbo & Àfò \\
\hline 2. & Stomach & Àfò & Áwhó \\
\hline 3. & Suffering & Áfó & Àwhúwhú \\
\hline 4. & Children & Áhúhú & Úmùázjì \\
\hline
\end{tabular}

This shows that Nwafija dialect makes use of an additional sound / $\Phi /$ that is not represented in the sound system of the standard Igbo language. 


\section{The syllable structure of Igbo Language}

A syllable is often a sequence of vowels and consonants and sometimes a syllabic consonant in a language uttered in a single vocal impulse. The Igbo syllable structure is such that the last speech sounds of most words are vowels. But in Nwafija dialect the consonant $/ \mathrm{n} /$ which can equally be called a syllabic nasal in Igbo language is used to end some words. The difference is the use of this sound in the two dialects. In Nwafija dialect some common words use this sound to end its word while the standard form does not use it in them.

TABLE SEVEN

\begin{tabular}{|c|c|c|c|}
\hline S/N & English & Standard Igbo & Nwafija dialect \\
\hline 1. & Now & Úgbúà & Údún \\
\hline 2. & Here & Ébéà & Kán \\
\hline
\end{tabular}

\section{Determination of relationship between Nawfija dialect and the standard variety of Igbo language}

This has to do with comparison between these two speech forms that are regarded as dialects of the same language to determine whether they are actually dialects of the same language or whether they are related languages. This can be determined by checking the cognate sets that is the relatedness and no relatedness between the two variants through the use of wordlist. One can calculate the percentage of corresponding items, percentage of lexical differences and percentage of phonological differences. The corresponding items are items that are exactly the same, phonologically different items are words that differ with one sound segment, while the divergent items are items that are lexically different.

\section{How to calculate cognate set}

The argument is that if you have $80 \%$ of Phonological Differences (PD) and corresponding item (CI) then you are dealing with a related languages and possibly dialects of the same language. This is to say that for these two speech forms to be referred to as dialects of the same language, they should have $80 \%$ level of cognacy.

\section{Formula}

From our data out of the 100 word list 80 are cognate, that it both corresponding items and phonologically different items. Thus the calculation is as follows:

This is to say that these two speech forms are dialects of the same language. Another factor is that of mutual intelligibility. This means the ability of speakers of different speech forms or different dialects to understand themselves. When there is mutual intelligibility; it indicates that the speech forms involved are dialects of the same language.

\section{B. Is Nawfija Dialect Inferior of the Standard Variety of Igbo Language?}

The above question is indeed an important one to be answered. The fact that there is a variety of a language referred to as the standard variety does not mean that every other dialect of that language is inferior. Rather the two variants are both means of communication in that language. Being that the choice of the standard form is not based on the best dialect but on political reasons, popularity of the dialect or that a particular man brought major development to his people in the olden days, like is the case with Yoruba standard variety, then we have to understand that even before such developments, that such communities were communicating well with their various dialects.

Furthermore, since there is mutual intelligibility among the speaker of Nawfija dialect and those of the standard variety, then none of the varieties is superior to the other. Moreover in some towns the elderly ones do not understand the Standard Igbo and for effective communication to be achieved, their dialect is used when communicating with them. Thus this explains that no dialect is inferior to the other, as far as the dialect has speakers, is mutually intelligible and there is achievement of effective communication.

\section{SUMMARY}

In summarizing the linguistic variation and change in Nawfija speech commonly the researcher observed that there are lexical and phonological variation between standard variety of Igbo language and the Nawfija dialect of Igbo. This was shown in the variations in section above. The researcher equally observed that these two speech forms are dialects of the same language. This was confirmed by the use of lexicostatistics. From a close observation of the data, the researcher observed that there are some sounds in Nawfija dialect which are absent in the sound system of Standard Igbo. These sounds are / 3/ (voiced palate alveolar fricative) and the sound / $\$$ / (voiceless bilabial fricative).

\section{A. Recommendation}

In the light of the findings of this research work, the study hereby presents some suggestions and recommendations for the development of the Igbo language, they are:

1. The two additional sounds used in Nawfija dialect / $3 /$ and / $\$ /$ that is the voiced palate alveolar fricative and the voiceless bilabial fricative should be accommodate in the orthography of standard Igbo.

2. A general understanding should be established among users of Igbo language that no variety of Igbo language is superior to the other.

3. To retain the existence of these dialects in future, users of the various dialects of Igbo language should be allowed to use them in writing for the preservation of cultural terms or concepts peculiar to these dialects. 


\section{B. Conclusion}

This research work is a contribution to the study of linguistic variation and dialectal variation in Igbo language. Through this work, it is observed that there is great percentage of cognates between standard Igbo and Nawfija dialect of Igbo. Hence the two dialects are mutually intelligible.

Due to the high level of mutual intelligibility between the two speech forms, we conclude that both are dialects of the same language and none is superior to the other.

Finally, it is also understood from this work that the sound system of standard Igbo can be enhanced by the addition of the two extra sounds used in Nawfija dialect of Igbo. The sounds are $/ 3 /$ and $/ \Phi /$. Since Igbo language is one of the major Nigeria languages which still need development, we suggest that other dialects of the language be investigated. The findings of these investigations will help to enhance both the lexicon and orthography of the standard variety.

\section{REFERENCES}

[1] Akmajian, A., Demers, R.A. and Harnish, R.M. (2004). Linguistics: An Introduction to Language and Communication $5^{\text {th }}$ Edition, India: Prentice Hall of India.

[2] Anabogu, P.N., Mbah, M.B. and Eme, C.A. (2001). Introduction to Linguistics. Awka: JFC LTD

[3] Essien, E.O. (1990). A grammar of the Ibibio Language. Ibadan: Ibadan University Press:

[4] http://en.citizendium.org/wiki/linguisticvariation.

[5] http://en.wikipedia.org./wiki/variation(linguistic).

[6] http://grammar.about.com/od/il/g/linguisticvariationterm.htm. (Online Sources All retrieved on 19/4/2021).

[7] Labov, W. (1972). The social stratification of (r) in New York City department stores: in sociolinguistics patterns. Philadelphia: University of Pennsylvania Press.

[8] Nwoga (1975). Junior Igbo Course. Ontisha: University Press Co.

[9] Olaoye, A.A. (2007). Introduction to sociolinguistics Abuja: Ogunleye publishing and printing press.

[10] Wardlaugh, R. (1993). An Introduction to sociolinguistics. London: Blackwell.

[11] Yule, G. (2004). The study of language $2^{\text {nd }}$ Edition, Cambridge: Cambridge University Press

Chineze Nwagalaku was born in Nawfija, Anambra state. She got BA and MA degrees in Linguistics, igbo and other Nigerian languages, University of Nigeria, Nsukka. Chineze is a member of Pragmatic Association of Nigeria.

Harriet Chinyere Obiora bagged BA in Linguistics from Ebonyi State University and MA in Linguistics from the University of Nigeria, Nsukka. Harriet specialises in Discourse Analysis and Pragmatic. She has published in Journal of language Teaching and Research, Vol 12, No.3, pp.494-500, May 2021. Mrs. obiora is a member of the Linguistics Association of Nigeria. She is also a PhD student in the Department of linguistics, igbo and other Nigerian languages, University of Nigeria Nsukka.

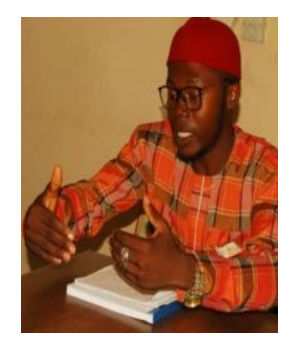

Christopher C. Nwike is a native of Onitsha, Onitsha North Local Government Area of Anambra State. He was born in Ogidi, Anambra State on the $3^{\text {rd }}$ of May. Christopher C. Nwike is a trained translator. Mr. Nwike belongs to the Association of Translation Studies in Nigeria. He also obtained an academic Merit Award in Honour of Aknu-ibiam As the Best Graduating Student Who Produced the Best Long Easy in Igbo Language in Linguistics Department, University of Nigeria, Nsukka. His areas of specialisation are Translation, Interpreting, Semantics and Studies in Igbo language. 